\title{
Variations in Number of Teeth and Asymmetry of the Skull in the Wolf
}

\author{
Tadeusz BUCHALCZYK, Janusz DYNOWSKI, \& Stanisław SZTEYN
}

\begin{abstract}
Buchalczyk T., Dynowski J. \& Szteyn S., 1981: Variations in number of teeth and asymmetry of the skull in the wolf. Acta theriol., 26, 2: 23-30 [With 2 Tables \& Plates I-II].

Analysis was made of the teeth in 234 wolf skulls obtained from Polish territory and from the eastern part of the Białowieża Primeval Forest (USSR). Authors describe three groups of deviation's from typical tooth pattern in wolves: polydonty, oligodonty and others types of tooth anomalies occurring when the normal number of teeth was present. There is a similar frequency of polydonty and oligodonty in Lublin voivodship and more southern voivodships Kraków and Rzeszów. In different geographical regions were observed a particular deviations from the teeth pattern, e.g., bilateral occurrence of additional $I^{2} I^{2}$ in skulls from the Bialystok voivodship an'd the eastern part of Bialowieża Primeval Forest; the bilateral absence of $M_{3}$ found only in the south Poland and bilateral skeweness of $P^{3}$ occurred only in wolves from Lublin voivodship. An increased number of teeth occurs more often in males than, in females.

[Mammals Res. Inst., Polish Acad. Sci., 17-230 Białowieża (TB) and Teachers Training Coll., Dept. Biol., Żołnierska 14, 10-561 Olsztyn].
\end{abstract}

\section{PURPOSE OF THE STUDY, MATERIAL}

The purpose of this study is to trace the occurrence of deviations from the normal tooth pattern (42 teeth) in the wolf, (Canis lupus Linnaeus, 1758), depending on sex and geographical region, and also to describe two cases of asymmetry in wolf skulls.

The material available from Poland consisted of 41 wolf skulls from the collection in the M. Curie-Skłodowska Univ., Lublin (UMCS), 98 wolves collected by the Mammals Research Institute of the Polish Academy of Sciences at Białowieża: (MRI) and 95 wolf skulls originating from the eastern part of the Bialowieża Primeval Forest and kept in the Zoological Museum of Moscow State University (MGU). In' this last case use was made of notes on tooth anomalies (cases of polydonty only), made by one of us (TB) when this series was studied in Moscow.

In part of the material derived from the former Lublin voivodship ${ }^{1}$ (UMCS material) the additional teeth had been removed, making it possible to examine the roots of these teeth. The remainder of tooth anomalies were examined only from the exterior, since the majority of skulls derived from collections of other

1 Use has of necessity been made in this study of the larger areas of former voivodships, as they were before the administrative reform of 1975 . 
institutes or private persons and studied when shown at trophies exibitions. The sex of the specimen was usually given with the skull, but in part of the material sex was identified on the basis of dimensions and appearance of the skull. It was only in 16 cases (out of over 200) that it proved impossible to determine sex. The skulls of adult and young wolves with a complete set of permanent teeth were used for the study.

\section{RESULTS}

In the study material the total number of teeth varied within limits of 40 to 44 . Deviations were found from the tooth pattern typical of the wolf in 25 cases $(10.7 \%$ ) (Table 1$)$. In this connection slight variants in differences in teeth were not taken into account, and also cases were omitted in which it was assumed that absence of teeth was due to mechanical injury.

It proved possible to distinguish three groups of deviations from typical tooth pattern in wolves: (1) increased number of teeth (polydonty) observed directly or concluded on the basis of the distinctly preserved alveoli, (2) decreased number of teeth - oligodonty; (3) other types of tooth anomaly occurring when the normal number of teeth were present.

More interesting cases of anomalies are described below in details: Wolf no. 833 has double $I^{2} I^{2}$ on both sides. This is a variant anological with that described by Dolgov \& Rossolimo (1964) in specimen no. S-55020 from the eastern part of the Białowieża Primeval Forest. In specimen no. 833 the left $I^{2}$ is set almost completely vertically to the sagittal plane of the skull (Fig. S, Plate I). Additional incisors are of almost normal size and there are traces of wear of the occlusal surface, particularly on the left one, where dentine is clearly exposed. An additional anomaly in this specimen is the marked sideways slant of $P_{4}$ on both sides (Fig. 2).

In specimen no. S-53795 the left $M^{3}$ is supernumerary, as can be concluded only from the preserved alveolus. This diagnosis has been confirmed by an independent record made by Dr. A. L. Ruprecht in 1968.

Wolf no. $14 / \mathrm{Lu}$, inspected at the hunting exhibition, had an additional $P^{1}$ with a crown in the shape of an irregular oval, $5.6 \mathrm{~mm}$ in diameter.

Two individuals (nos. 9 and 2 UMCS) have additional premolars in the right mandible. In the first case the additional tooth has turned about $60^{\circ}$ round its own axis in the alveolus towards the median side, in relation to the long axis of the tooth row (Fig. 3). This has caused $P_{2}$ to shift slightly backwards about $2 \mathrm{~mm}$ in comparison with $P_{2}$ of the left mandible. Its appearance has not visibly affected the position or altered the shape and dimensions of $P_{1}$. It is most similar to the 
Table 1

Variability of teeth pattern of Canis lupus Linnaeus, 1758.

\begin{tabular}{|c|c|c|c|c|}
\hline Number \& Coll. & Sex & $\begin{array}{l}\text { Place and date } \\
\text { of killing }\end{array}$ & Description & $\begin{array}{l}\text { Total } \\
\text { No. of } \\
\text { teeth }\end{array}$ \\
\hline \multicolumn{5}{|c|}{ Supernumerary teeth } \\
\hline S-55034, MGU & M & $\begin{array}{l}\text { Eastern part of Bia- } \\
\text { lowieża Forest, III } 51\end{array}$ & 1. »double « $P_{1}$ & $(43)$ \\
\hline S-55020, MGU & $\mathrm{M}$ & Białowieża F. II 51 & 1. +r. double $I^{2} I^{2}$ & 44 \\
\hline $\begin{array}{l}\text { 833, MRI } \\
\text { S-55026, MGU }\end{array}$ & $\begin{array}{l}\mathrm{M} \\
\mathrm{M}\end{array}$ & $\begin{array}{l}\text { Białystok voiv. } \\
\text { Białowieża F. III } 49\end{array}$ & $\begin{array}{l}\text { 1. }+\mathrm{r} \text {, double } I^{2} I^{2} \\
\text { r. tooth between } P^{1}\end{array}$ & $44^{1,2}$ \\
\hline S-53780, MGU & M & Bialowieża F. I. 51 & $\begin{array}{l}\text { and } P^{2} \\
\text { r. } P_{1} \text { between } C_{1}\end{array}$ & 43 \\
\hline S-53797, MGU & M & Białowieża F. I 49 & $\begin{array}{l}\text { and } P_{1} \\
\text { l. } P \text { between } P_{1}\end{array}$ & 43 \\
\hline S-55788, MGU & F & Białowieża F. I 51 & $\begin{array}{l}\text { and } P_{2} \\
\text { 1. } P \text { between } C_{1}\end{array}$ & 43 \\
\hline S-53795, MGU & F & Białowieża F. III 49 & $\begin{array}{l}\text { and } P_{1} \\
\text { 1. } M^{3} \text { (alveola) } \\
\text { r. } P^{1} \text { between } P^{1}\end{array}$ & $\begin{array}{l}43 \\
43\end{array}$ \\
\hline 14/Lu., MRI & $?$ & Sosnowica, 1966 & and $P^{2}$ & 43 \\
\hline 9, UMCS & M & Kijowiec, XII 61 & $\begin{array}{l}\text { r. } P_{1} \text { between } P_{1} \\
\text { and } P_{2}\end{array}$ & $43^{3}$ \\
\hline 2, UMCS & M & Międzyrzec, X 61 & $\begin{array}{l}\text { r. } P_{1} \text { between } P_{1} \\
\text { and } P_{2}\end{array}$ & $43^{4}$ \\
\hline $\begin{array}{l}\text { 40, UMCS } \\
\text { 78/Kr., MRI }\end{array}$ & $\begin{array}{l}\mathrm{M} \\
\mathrm{M}\end{array}$ & $\begin{array}{l}\text { Janów Lubelski, II } 69 \\
\text { Muszyna, II } 56\end{array}$ & $\begin{array}{l}\text { 1. } M_{4} \\
\text { 1. } P_{1} \text { between } C_{1}\end{array}$ & $43^{5}$ \\
\hline 840, MRI & M & Rzeszów voiv., $60-65$ & $\begin{array}{l}\text { and } P_{1} \\
\text { r. } P_{1} \text { between } C_{1} \\
\text { and } P\end{array}$ & 43 \\
\hline 107967, MRI & $\mathrm{F}$ & West Bieszczady Mts. & r. $P_{1}$ between $C_{1}$ & 43 \\
\hline 107969, MRI & M & West Bieszczady Mts. & $\begin{array}{l}\text { and } P_{1} \\
\text { r. } P_{1} \text { between } C_{1} \\
\text { and } P_{1}\end{array}$ & 43 \\
\hline \multicolumn{5}{|c|}{ Missing teeth } \\
\hline 70/01., MRI & $\mathrm{F}$ & Gierdawy, III 58 & $1 M_{3}$ & 41 \\
\hline $\begin{array}{l}\text { 27, UMCS } \\
28 \text { UMCS }\end{array}$ & $\mathrm{F}$ & Kryńszczak, XII 67 & 1. +r. $M_{3} M_{3}$ & $40^{7}$ \\
\hline $\begin{array}{l}28, \text { UMCS } \\
7 / \mathrm{Kr} \text { MRI }\end{array}$ & $\begin{array}{l}\mathrm{F} \\
\mathrm{F}\end{array}$ & Pobołowice, XII 67 & 1. $M_{3} ; M_{2}$ with 3 roots & $\begin{array}{l}41^{6} \\
40\end{array}$ \\
\hline 43/Kr., MRI & ? & $\begin{array}{l}\text { Muszyna, } 66 \\
\text { Nawojowa, XII } 68\end{array}$ & $\begin{array}{l}1 .+ \text { r. } M_{3} M_{3} \\
\text { r. } M_{3}\end{array}$ & $\begin{array}{l}40 \\
41\end{array}$ \\
\hline 796, MRI & $\dot{M}$ & Dobcza, II 53 & $1 .+$ r. $M_{3} M_{3}$ & 40 \\
\hline 111945, MRI & $\mathrm{M}$ & Brzegi Dolne, XII 69 & $1 .+$ r. $M_{3} M_{3}$ & 40 \\
\hline \multicolumn{5}{|c|}{ Another teeth anomalies } \\
\hline 13/Lu., MRI & M & Sosnowica, 1956 & $\begin{array}{l}\text { 1. }+ \text { r. not completely } \\
\text { erupted } P^{1} p^{1}\end{array}$ & $(42)$ \\
\hline $\begin{array}{l}\text { 19, UMCS } \\
\text { 4. UMCS }\end{array}$ & $\mathrm{M}$ & Józefów, XII 61 & 1. + r. skewed $P^{s} P^{s}$ & \multirow{6}{*}{$\begin{array}{l}42^{8} \\
42 \\
42 \\
42\end{array}$} \\
\hline 4. U & & $\begin{array}{c}\text { Lubycza Królewska, } \\
\text { VII } 64\end{array}$ & 1. + r, skewed $P^{3} P^{3}$ & \\
\hline $\begin{array}{l}31 \text {, UMCS } \\
6 \text {, UMCS }\end{array}$ & M & Lipa, I 68 & 1. + r. skewed $P^{3} P^{3}$ & \\
\hline & & \multirow{3}{*}{\multicolumn{2}{|c|}{$\begin{array}{ll}\text { Another skulls anomalies } \\
\begin{array}{ll}\text { Sobibór, III } 62 & \text { asymmetry skull's } \\
& \text { constitution } \\
& \text { asymmetry skull's } \\
\text { constitution, shape } & \end{array}\end{array}$}} & \\
\hline 14, UMCS & M & & & \\
\hline 25, UMCS & $\mathrm{F}$ & & & \\
\hline
\end{tabular}


latter, but is slightly smaller (length measured on cingulum is $1 \mathrm{~mm}$ smaller, and height of tooth $2 \mathrm{~mm}$ shorter). Its crown is also of a less complex shape. The root is similar to a cone and does not exhibit the characteristic lateral flattening. In its distal part there is a very sligh: swelling. In the second case the supernumerary premolar does no: differ from $P_{1}$ in respect of shape and dimensions of the crown (Fig. 4). It has caused the teeth adjoining it to move slightly apart. Immediately below the neck of the tooth there is unusual enlargement of the root ( $1 \mathrm{~mm}$ larger in comparison with $P_{1}$ ), which is markedly buccally bent halfway along its length. Sulci indicating the division of the root into two parts run along the lingual and buccal side.

Skull no. 40 has as many as four molars in the left mandible (Fig. 5). Specimen no $78 / \mathrm{Kr}$ has an additional tooth situated in front of the true $P_{1}$ in the left half of the mandible. The two teeth are separated by an interval of about $2 \mathrm{~mm}$, and the maximum diameter of ithe supernumerary $P_{1}$ was $4.8 \mathrm{~mm}$. Skull no. 840 (MRI) has a similar additional right lower premolar situated between $C_{1}$ and the $P_{1}$, with a simplified conical crown, $4.8 \mathrm{~mm}$ long and $4.5 \mathrm{~mm}$ wide. This tooth protrudes from the alveolus to a height of $6.2 \mathrm{~mm}$ and its occlusal surface is clearly worn. It has caused constriction of the tooth row and its simultaneous elongation by $1 \mathrm{~mm}$ (measurement from $P_{1}$ to $M_{3}$ ).

The skull labelled coll. no. 107967 (MRI) is a trophy from the collection of W. Pepera, M. Sc. In the right half of the mandible it has an additional $P_{1}$, with the apex directed lingually. Another skull, no. 107969, from the same collection, has an additional $P_{1}$ with the apex pointing backwards and root visible from the exterior. In additional right $P^{2}$ and $P^{3}$ are missing, without any trace of alveoli, but this may have been caused by mechanical injury (?). This is an adult wolf with only slight degree of tooth wear.

In oligodont dentition repeated cases of unilateral absence of $M_{3}$ (e.g., mandible no. 28, Fig. 6) or absence of the last molars on both sides (mandible no. 27, Fig. 7) were observed. Bilateral absence of $M_{3}$ occurred in 4 cases. One of these skulls was determined as a probable bastard of wolf with a dog (no. 111945, Table 1), killed in the field. In this specimen in place of $M_{3}$ alveoli there are only small shallow foramina about $1.5 \mathrm{~mm}$ in diameter, not indicating that they could have been what was left after loss of the teeth. We have considered this as a case of oligodonty?

2 In the MRI collection at Bialowieża there is also skull no. 837,F, ad. Canis familiaris, shot in May 1965, in the area of the Forest Administration. Unit of Gładyszów, Rzeszów voivodship, and incorrectly indentified by a hunter as a wolf. Both $\mathrm{M}_{2}$ and $\mathrm{M}_{3}$ are missing from the preserved right mandible of this specimen. There are no traces of alveoli, the bone is completely smooth in this 
In wolf no. 798 of unknown origin there is no right $P_{3}$ or traces of its alveolus, while the bone from the side of the right half of the mandible is more pitted than that from the side of the left $P_{3}$. We considered this to be a case of probably natural oligodonty.

Wolf no. 13/Lu exhibits an interesting tooth anomaly (Table 1 ), $P^{1}$ on both sides exhibiting retarded development (only just protruding from the alveoli). The left tooth, the larger of the two, is about $3.5 \mathrm{~mm}$ high. During the animal's life these teeth probably did not protrude above the gum, and did not therefore participate in biting. The surface of their enamel is matt.

In skull no. 4 (UMCS) $P^{8} P^{8}$ are situated obliquely in comparison with the situation of these teeth in most wolves. Usually the line forming the extension of the long axis of the crown of $P^{3}$ runs between prosthion, and the proximal margin of the alveolus of the canine tooth on the opposite side, and forms with the long axis of the skull an angle of $20^{\circ}-40^{\circ}$. In this case the angle attains a value of $70^{\circ}$ for the left, and $80^{\circ}$ for the right tooth (Fig. 8). The skewed position of $P^{3} P^{3}$ is accompanied by reduction of about $4.5 \mathrm{~mm}$ in the distance between $P^{2}$ and $P^{4}$ from both sides of the maxilla, in comparison with the mean value for skulls of similar size. In addition accumulation of bone tissue can be seen in the form of protuberances in the median and lateral walls of the alveoli. Changes connected with the turn of $P^{3} P^{3}$ round the axis running through the root and crown also occur in the two other specimens (coll. UMCS 19 and 31, Table 1). In these skulls the teeth referred to are situated obliquely and also asymmetrically in relation to each other, but deviations do not attain the degree observed in the individual no. 4.

Anomalies of a different kind, are asymmetries of the skulls. They were found in two animals: no. 14 (Fig. 9) and no. 25 (Fig. 10). They have several deformed bones in the splanchno- and neurocranium (praesphenoideum, basisphenoideum, basioccipitale, processus zygomatrcus, palatinum, vomer, pterigoideum). Changes in the bones are accompanied by distortion of the skull in the sagittal plane (to the right). In the case of no. 25 distortion is connected with the slight turn of the braincase to the left in relation to the facial part.

Regional differences in frequency of polydonty are considerable

place, with only one very small nutritive foramen. There is nothing to suggest that the missing teeth had been lost secondarily. The absence of the left mandible made it impossible to determine if this anomaly had been bilateral. Mention is made of this case, as the bastard killed in Bieszczady Mts. four years later indicates that crossbreeding takes place in the Rzeszow voivodship between wolves and large wolf-like dogs which have gone wild. Furthermore the similarity of the anomalies merits attention. 
(Table 2) but they are statistically insignificant (Chi-square test). In the Lublin voivodship and the southern voivodships Krakow and Rzeszów, both polydonty and oligodonty occur in approximately uniform proportions.

A number of teeth deviating from the normal tooth pattern in volves occurs twice or even three times more often in males than in females in samples from different regions. The numbers are too small, hovewer, to permit of accurate statistical calculations of samples. The difference in the number of tooth anomalies in males and females is statistically insignificant $\left(\chi^{2}=1.406 ; 0.2<p<0.3\right)$.

Table 2

The frequency of the anomalies in wolves' skull according to geographical regions.

\begin{tabular}{|c|c|c|c|c|c|c|c|c|c|c|}
\hline \multirow[b]{2}{*}{$\begin{array}{l}\text { Supernumerary } \\
\text { teeth }\end{array}$} & \multicolumn{2}{|c|}{$\begin{array}{c}\text { Olsztyn, } \\
\text { Białystok and } \\
\text { eastern part } \\
\text { of Białowieża } \\
\text { Forest } \\
N=125\end{array}$} & \multicolumn{2}{|c|}{$\begin{array}{l}\text { Lublin } \\
58\end{array}$} & \multicolumn{2}{|c|}{$\begin{array}{c}\text { Kraków, } \\
\text { Rzeszów } \\
37\end{array}$} & \multicolumn{2}{|c|}{$\begin{array}{l}\text { Poland } \\
14\end{array}$} & \multicolumn{2}{|c|}{$\begin{array}{l}\text { Total } \\
234\end{array}$} \\
\hline & $\begin{array}{l}n \\
8\end{array}$ & $\begin{array}{l}\% \\
6.4\end{array}$ & $\begin{array}{c}\mathrm{n} \\
4\end{array}$ & $\begin{array}{l}\% \\
6.9\end{array}$ & $\begin{array}{l}\mathrm{n} \\
4\end{array}$ & $\begin{array}{c}\% \\
10.8\end{array}$ & $\underline{n}$ & $\%$ & $\begin{array}{c}\mathrm{n} \\
16\end{array}$ & $\begin{array}{l}\% \\
6.8\end{array}$ \\
\hline Missing teeth & 1 & 0.8 & $3^{1}$ & 5.2 & 4 & 10.8 & 1 & $(7.1)$ & 9 & 3.9 \\
\hline Total & 9 & 7.2 & 7 & 12.1 & 8 & 21.6 & 1 & $(7.1)$ & 25 & 10.7 \\
\hline
\end{tabular}

${ }^{1}$ Including specimen no. $13 / \mathrm{Lu}$. with not completely erupted $\mathrm{P}^{\mathbf{1}} \mathrm{P}^{\mathbf{1}}$.

\section{DISCUSSION}

Variation in the number and position of teeth, analysed e.g., by Colyer (1936), Döcke (1959), and Reinwaldt (1963, cited after Dolgov \& Rossolimo, 1964), Deadern (1960), Dolgov \& Rossolimo (1964) and Ruprecht $(1965,1978)$ is qualitatively similar in different species of Carnivora, but frequency of particular tooth patterns may fluctuate within wide limits. It was found, for instance, that polydont set of teeth occur more often in foxes $\left(3.5^{\circ} \%\right)$ than in wolves $(1.8 \%)$.

The cases observed of particular deviations from the normal tooth pattern in wolves merit closer attention, since although their frequencies in different regions appear to be statistically insignificant, they would appear to depend on the geographical region. For instance, an analogical anomaly of bilateral occurrence of additional $I^{2} I^{2}$ in male wolves was observed in skulls from the Białystok voivodship and the eastern part of the Białowieża Primeval Forest (USSR). The bilateral absence of $M_{3}$ was found only in the south of Poland, but this anomaly was not observed in material from the north of Poland $(n=22)$ available 
for a repeat examination. The three similar cases of bilateral skeweness of $P^{s}$ occurred only in wolves from the Lublin voivodship.

Similar results giving statistically non-significant differences in the tooth pattern of Mustela putorius Linnaeus, 1758, depending on sex, and population (Białowieża and Rzeszów) were obtained by Ruprecht (1978). A statistically highly significant difference was, however, observed in the frequencies of oligodonty in female polecats depending on age. The small amount of material available prevented us from checking differences depending on the age of the wolves.

All these particular and yet diverse differences would appear to show that at least some teeth anomalies in wolves can be treated a features of the morphotype, important in regional studies of different populations (cf. also Yablokov, 1978).

Acknowledgements: The authors wish to tender their thanks to all those who by re-checking material, carrying out statistical calculations and correcting the text contributed to a fuller presentation of these results. We must therefore acknowledge our debt to Dr. A. L. Ruprecht, Dr. S. Fedyk and Professor Z. Pucek.

\section{REFERENCES}

1. Deadern' L. C., 1960: Extra premolars in the River otter (Lutra canadensis). J. Mammal., 35: 125-126.

2. Dolgov V. A., Rossolimo O. L., 1964: Dental abnormalities in Canis lupus Linnaeus, 1758. Acta theriol., 8: 237-244. [In Russian with English summary].

3. Yablokov A. V., 1978: History, contemporary state and ways of development of phenetic investigation. [In: "The physiological and populational ecology of animals ]. 5 (7): 5-12. Saratov State Univresity [In Russian].

4. Ruprecht A., 1965: Anomalies of the teeth and asymmetry of the skull in Erinaceus europaeus Linnaeus, 1758. Acta theriol., 10: 234-236.

5. Ruprecht A. L., 1978: Dentition variations in the common polecat in Poland. Acta theriol., 23: 239-245.

Accepted, September 15, 1980.

Tadeusz BUCHALCZYK, Janusz DYNOWSKI i Stanisław SZTEYN ZMIENNOSC UZĘBIENIA ORAZ ASYMETRIA CZASZEK U WILKA

\section{Streszczenie}

Przeprowadzono analizę uzębienia 234 czaszek wilków pochodzących z terenu Polski oraz we wschodniej części Puszczy Białowieskiej (ZSRR). Stwierdzono występowanie 25 przypadków $(10,7 \%)$ odmiennego typu uzębienia, wśród których możra wyróżnić: polidoncję, oligodoncję oraz inne typy zmienności, występujące przy zgodnej $\mathrm{z}$ wzorem liczbie zębów. Odmienne warianty uzębienia, zwłaszcza polidoncja, częściej występują u samców niż u samic (Tabela 1). Na terenie wo- 
jewództwa lubelskiego oraz województw południowo-wschodnich: krakowskiego i rzeszowskiego, ilość przypadków polidoncji i oligodoncji jest zbliżona (Tabela 2).

$\mathrm{Na}$ uwagę zasługują przypadki szczególnych anomalii uzębienia wilka powtarzające się na tym samym terenie: dodatkowe $I^{2} I^{2}$ (Ryc. 1) stwierdzone u samców wilków z terenu województwa białostockiego oraz ze wschodniej części Puszczy Białowieskiej; cztery przypadki braku $M_{3} M_{3}$ (Ryc. 7) stwierdzone na terenie poludniowo-wschodniej Polski; wystąpienie skośnie osadzonych $P^{3} P^{3}$ (Ryc. 8) trzy przypadki $z$ terenu województwa lubelskiego. Opisano dwa przypadki asymetrii czaszek wilków z terenu województwa lubelskiego.

\section{EXPLANATION OF PLATES I-II}

\section{Plate I}

Fig. 1. Skull of wolf no. 833. Supernumerary $I^{2} I^{2}$.

Fig. 2. Mandible of wolf no. 833. $\mathrm{P}_{4} \mathrm{P}_{4}$ slanting sideways.

Fig. 3. Mandible of wolf no 9. Supernumerary $P_{1}$ between $P_{1}$ and $P_{2}$. Fig. 4. Mandible no. 2. Supernumerary $P_{1}$ between $P_{1}$ and $P_{2}$.

Fig. 5. Specimen no. 40. Part of the left mandibular bone with visible $M_{4}$.

Fig. 6. Specimen no. 28. Part of the left mandibular bone without $M_{3}$, unilateral retention.

Plate II

Fig. 7. Mandibie no. 27. Bilateral retention of $M_{3} M_{3}$.

Fig. 8. Skull no 4. Jaw with anormally positioned $P^{3} P^{3}$.

Fig. 9. Skull, no. 14 with assymetrical structure.

Fig. 10. Skuil no. 25 with assymetrical structure. Detailed description in text. 

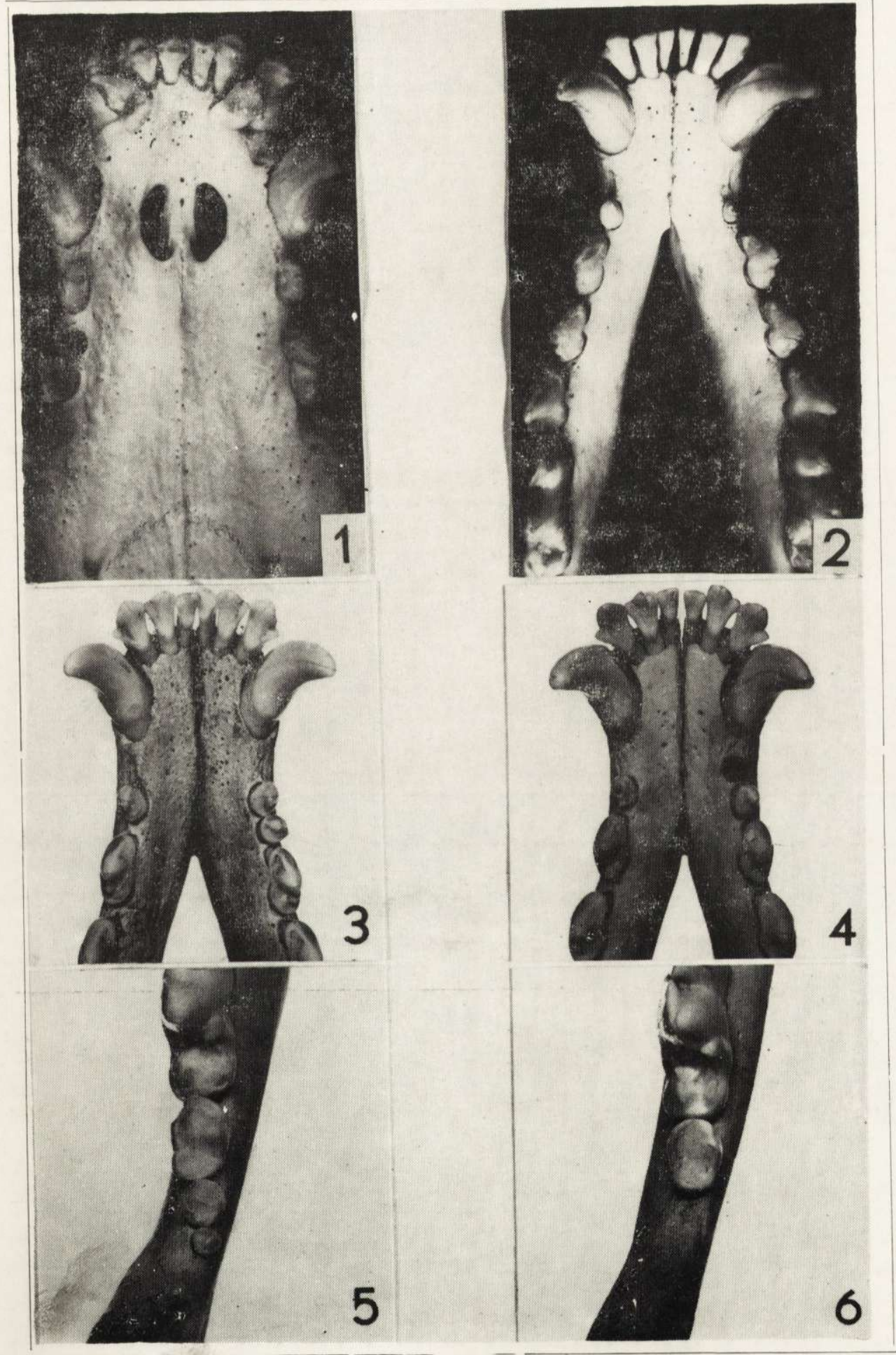

T. Bucbalczyk et. al.

S. Buszko phot. 1, 2; J. Dynowski phot. 3-6 
ACTA THERIOLOGICA, XXVI, 2

Plate II

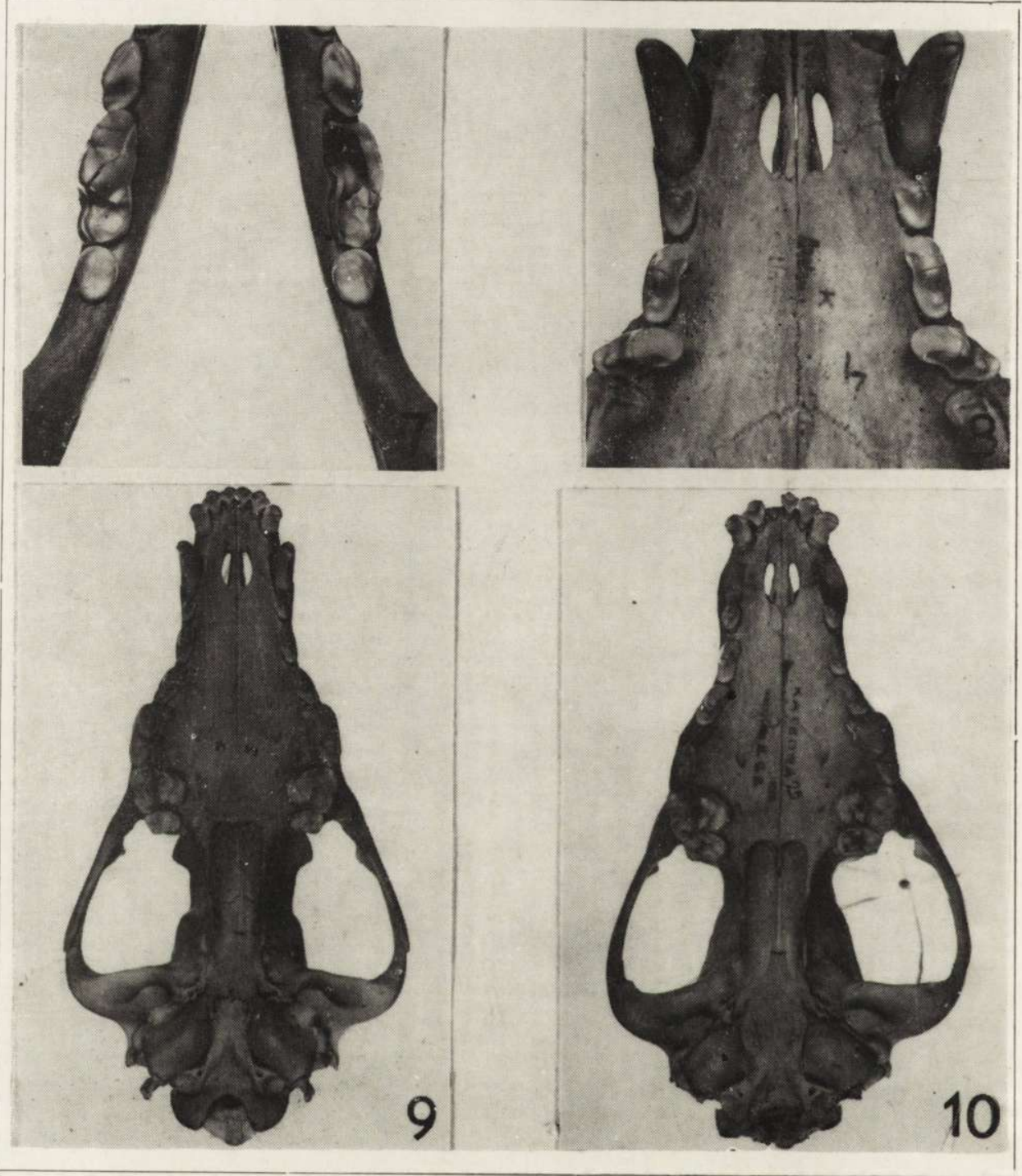

T. Buchalczyk et al.

J. Dynowski phot. $7-10$ 